\title{
VALIDASI METODA PENGUJIAN KANDUNGAN KALSIUM, MAGNESIUM, DAN SENG DALAM PELUMAS DENGAN SPEKTROMETRI SERAPAN ATOM (SSA) MENGGUNAKAN TEKNIK PELARUTAN LANGSUNG OLEH XILENA
Method Validation for Determination of Calcium, Magnesium, and Zinc Content in by Xylene Lubricant by Atomic Absorption Spectrometry (AAS) using Direct Dilution Technique
}

\author{
Deni Cahyadi ${ }^{1}, 2$, Eny Susilowati ${ }^{1}$, M. Arsyansyah ${ }^{1}$, Indra Hadiwijaya ${ }^{1}$, Azio Oka Darmana ${ }^{3}$, Keke $^{2}$ \\ Wanda Manola ${ }^{3}$ dan Rijal Desiana ${ }^{3}$ \\ ${ }^{1}$ Balai Besar Bahan dan Barang Teknik, Jl. Sangkuriang No.14 Bandung \\ ${ }^{2}$ Fakultas Teknik Mesin dan Dirgantara, Institut Teknologi Bandung, Jl. Ganesha No.10 Bandung \\ ${ }^{3}$ Universitas Jenderal Ahmad Yani, Jl. Terusan Jend. Sudirman, Cibeber - Cimahi. \\ e-mail : denb4t@gmail.com
}

Diterima: 18 Oktober 2019 Direvisi: 18 September 2020 Disetujui: 26 Desember 2020

\begin{abstract}
Abstrak
Pengujian kandungan unsur logam kalsium, magnesium, dan seng di dalam minyak pelumas menggunakan spektrometri serapan atom dengan teknik pelarutan langsung oleh xilena telah dilakukan. Kandungan unsur logam tertentu (seperti: kalsium, magnesium, dan seng) merupakan salah satu parameter syarat mutu SNI wajib pelumas yang harus dipenuhi. Menurut SNI, terdapat dua pilihan metode uji yang dapat dijadikan acuan untuk melaksanakan pengujian kandungan unsur logam dalam minyak pelumas, yaitu dengan menggunakan ICP-AES atau AAS. Pada penelitian ini contoh minyak pelumas dilarutkan secara langsung dengan xilena, kemudian dilakukan pengukuran dengan AAS. Penggunaan teknik persiapan contoh dengan pelarutan secara langsung menggunakan xilena, diharapkan dapat menyederhanakan proses pengujian dibandingkan dengan menggunakan cara pelarutan asam. Hasil pengukuran pada percobaan yang dilakukan menunjukkan bahwa, linearitas kurva kalibrasi $\left(R^{2}\right)$ untuk $C a=$ 0,99640; $\mathrm{Mg}=0$ 0,99968; dan $\mathrm{Zn}=0,99938$; dengan nilai presisi untuk $\mathrm{Ca}=2,168(\% \mathrm{RSD})<3,914\left(0.67^{*} \mathrm{CV}\right.$ Horwitz); $\mathrm{Mg}=1,265<5,670$; dan $\mathrm{Zn}=0,665<4,736$; \%rekoveri $\mathrm{Ca}=101 \%, \mathrm{Mg}=98 \%, \mathrm{Zn}=98 \%$; batas deteksi (LoD): $\mathrm{Ca}=0,013 \mathrm{mg} / \mathrm{L} ; \mathrm{Mg}=0,002 \mathrm{mg} / \mathrm{L} ;$ dan $\mathrm{Zn}=0,014 \mathrm{mg} / \mathrm{L} ;$ dan nilai LoQ: Ca = 0,043 mg/L; $\mathrm{Mg}=0,007 \mathrm{mg} / \mathrm{L}$; dan $\mathrm{Zn}=0,048 \mathrm{mg} / \mathrm{L}$. Parameter validasi (linearitas, presisi, akurasi, batas deteksi, dan batas kuantifikasi) yang diperoleh dari hasil pengujian ini relative dapat diterima. Proses persiapan larutan untuk pengujian dengan AAS dengan menggunakan xilena jauh lebih cepat dan sederhanan dibandingkan dengan pelarutan menggunakan asam.
\end{abstract}

Kata kunci : Validasi, pelumas, kalsium, magnesium, seng, xilena, SSA

\begin{abstract}
The elemental analysis of calcium, magnesium, and zinc in lubricating oil using Atomic Absorption Spectrometry by direct dissolution technique with xylene has been carried out. Certain metal elements (i.e. calcium, magnesium, and zinc) content were included in the mandatory SNI requirements. According to SNI, there are two choices of test methods that can be used as a reference for carrying out testing for metal content in lubricating oil, namely by using ICP-AES or AAS. In this study, samples of lubricating oil were directly dissolved with xylene, then measured by $A A S$. The use of sample preparation techniques with this method is expected to simplify the process compared to the acid digestion method. The measurement results show that, the linearity of the calibration curve, $R^{2}(\mathrm{Ca})=$ 0.99640; $R^{2}(\mathrm{Mg})=0.99968$; and $R^{2}(\mathrm{Zn})=0.99938$; repeatability value:\% $R S D(\mathrm{Ca})<0.67^{*} \mathrm{CV}-\mathrm{Horwitz}=2,168<$ 3,914; \%RSD $(\mathrm{Mg})<0.67^{*} \mathrm{CV}$-Horwitz = 1,265 < 5,670; and \%RSD $(\mathrm{Zn})<0.67^{*} \mathrm{CV}$-Horwitz = $0.665<4.736$; $\%$ recovery: $\mathrm{Ca}=101 \%, \mathrm{Mg}=98 \%$, and $\mathrm{Zn}=98 \%$; for $\mathrm{LoD}$ values: $\mathrm{Ca}=0.013 \mathrm{mg} / \mathrm{L} ; \mathrm{Mg}=0.002 \mathrm{mg} / \mathrm{L} ;$ and $\mathrm{Zn}=$ $0.014 \mathrm{mg} / \mathrm{L}$; and $\mathrm{LoQ}$ value: $\mathrm{Ca}=0.043 \mathrm{mg} / \mathrm{L} ; \mathrm{Mg}=0.007 \mathrm{mg} / \mathrm{L}$; and $\mathrm{Zn}=0.048 \mathrm{mg} / \mathrm{L}$. The validation parameters (linearity, precision, accuracy, limit of detection, and limit of quantification) obtained from the test results are relatively acceptable. The process of preparing solutions for testing with AAS using xylene is much faster and simpler than using acid digestion.
\end{abstract}

Keywords : Validation, lubricant, calcium, magnesium, zinc, xylene, AAS 


\section{PENDAHULUAN}

Minyak pelumas (lubricant oil) untuk kendaraan bermotor pada tahun 2018 telah ditetapkan menjadi salah satu produk industri yang harus mencantumkan tanda SNI pada kemasannya. Regulasi SNI wajib untuk 7 (tujuh) jenis pelumas kendaraan bermotor ditujukan untuk produk lokal dan impor, dan mulai diberlakukan pada bulan September 2019. Produk minyak pelumas yang diwajibkan untuk memiliki sertifikasi SNI menurut Permenperin No.25 tahun 2018, adalah sebagai berikut: (1) SNI 7069.1:2012, Minyak lumas motor bensin 4 (empat) langkah kendaraan bermotor; (2) SNI 7069.2:2012, Minyak lumas motor bensin 4 (empat) langkah sepeda motor; (3) SNI 7069.3:2016, Minyak lumas motor bensin 2 (dua) langkah dengan pendingin udara; (4) SNI 7069.4:2017, Minyak lumas motor bensin 2 (dua) langkah dengan pendingin air; (5) SNI 7069.5:2012, Minyak lumas motor diesel putaran tinggi; (6) SNI 7069.6:2017, Minyak lumas roda gigi transmisi manual dan garden; dan (7) SNI 7069.7:2017, Minyak lumas transmisi otomatis (Kemenperin, 2018).

Pelumas pada kendaraan bermotor pada umumnya berfungsi untuk mengurangi keausan akibat gesekan yang terjadi pada komponen mesin. Pelumasan yang baik dapat menjaga performa mesin kendaraan(Srivyas \& Charoo, 2019), menurunkan konsumsi bahan bakar, dan mengurangi emisi gas buang(Holmberg et al., 2012). Kandungan aditif dalam pelumas sangat mempengaruhi kualitas pelumas yang digunakan(Merry Mitan et al., 2018).

Syarat mutu pelumas menurut SNI meliputi persyaratan fisika, kimia, dan unjuk kerja. Persyaratan kimia mencakup kandungan unsur logam dan non-logam tertentu, yaitu: sulfur, fosfor, Nitrogen, kalsium, magnesium, dan seng. Kandungan unsur logam kalsium, magnesium, dan seng dalam pelumas merupakan salah satu parameter yang disyaratkan dalam produk pelumas SNI wajib, yaitu pada SNI 7069.1(BSN, 2012a), SNI 7069.2(BSN, 2012b), SNI 7069.3(BSN, 2016), SNI 7069.4(BSN, 2017a), SNI 7069.5(BSN, 2012c), dan SNI 7069.7(BSN, 2017b). Kandungan logam dalam pelumas pada umumnya berasal dari bahan aditif yang ditambahkan ke dalam minyak dasar(Roslan et al., 2016) dan akan sangat mempengaruhi terhadap karakteristik produk yang dihasilkan(Uflyand et al., 2019).

Metode uji kandungan logam yang diacu oleh SNI terdapat dua alternatif metode, yaitu: ASTM D4628 dan ASTM D 5185(BSN,
2012a)(BSN, 2012b)(BSN, 2016)(BSN, 2017a)(BSN, 2012c)(BSN, 2017b). Metode acuan tersebut memiliki perbedaan yang jelas, terutama pada peralatan utama yang digunakan. Menurut ASTM D5185, pengujian dilakukan dengan menggunakan ICP-AES, sedangkan di dalam ASTM D 4628 digunakan AAS(ASTM, 2018)(ASTM, 2016a). Metode lain yang dapat digunakan untuk pengujian logam dalam pelumas adalah dengan XRFSpectrofotometer(Pouzar et al., 2001).

Pengujian kandungan logam dalam produk pelumas harus dilaksanakan di pabrik atau produsen pelumas, sebagai salah satu upaya penjaminan mutu produk yang wajib dilakukan sebagaimana tercantum pada Permenperin No.25 tahun 2018, Lampiran I, butir F.III.3(Kemenperin, 2018). Penggunaan metode uji yang akurat dan ekonomis menjadi pertimbangan penting bagi pihak pabrik dalam memilih peralatan yang akan digunakan.

Tujuan dari kajian ini adalah untuk mengetahui kualitas dan keberterimaan metode uji kandungan logam (kalsium, magnesium, dan seng) oleh Spektrometri Serapan Atom (SSA) menggunakan xilena sebagai pelarut alternatif denga teknik pelarutan langsung, sebagai upaya untuk mendukung penggunaan metode uji yang cepat, relatif lebih murah dan akurat.

\section{TINJAUAN PUSTAKA}

Minyak pelumas merupakan suatu material yang pada umumya terdiri dari minyak dasar (base oil) dan bahan lainnya yang disebut aditif. Minyak dasar merupakan komponen pelumas yang utama, dengan kandungan dapat mencapai lebih dari $95 \%$ dalam suatu produk pelumas. Komponen aditif secara prosentase kandungan dalam pelumas pada umumnya tidak terlalu besar, tetapi memiliki dampak yang sangat menentukan terhadap keseluruhan kualitas pelumas. Komponen aditif yang ditambahkan kedalam pelumas dapat berupa senyawa organologam (metal containing organic compound), seperti anti-oksidan (calcium phenates, magnesium salicylate), antiwear (zinc dialkyldithiophosphates, ZnDTP), detergen, demulsifier, dan inhibitor korosi(Bartels \& Et.all, 2007). Material halus seperti attapulgite (magnesium alumunium silicate)(Nan et al., 2015), kalsium(Özcan et al., 2019) dan nano-ZnO digunakan juga sebagai aditif anti aus(Vardhaman et al., 2020). Penambahan aditif dalam pelumas sangat mempengaruhi kualitas dari suatu produk pelumas. 
Menurut ASTM D4628, penentuan kandungan logam dalam oli dapat dilakukan dengan alat AAS dengan cara pelarutan langsung (direct dilution) menggunakan pelarut kerosin (kerosene). Rentang kandungan yang dilingkupi oleh metode ini untuk kalsium dan magnesium sebesar $0,002 \%$ s.d. $0,3 \%$; dan seng sebesar $0,002 \%$ s.d. $0,2 \%$. Nilai repeatability bervariasi tergantung kandungan dan jenis logam yang diukur, sedangkan akurasi (bias) tidak dicantumkan(ASTM, 2016a).

Metode pelarutan berbasis air atau asam dapat digunakan untuk menentukan kandungan logam dalam suatu contoh pelumas. Pelumas yang merupakan senyawa organik terlebih dahulu didestruksi dengan asam sulfat, asam nitrat pekat, dan asam peroksida (acid digestion) pada suhu sampai $170^{\circ} \mathrm{C}$ selama satu jam, kemudian diencerkan dengan air dan diukur dengan flame-AAS(Zmozinski et al., 2010).

Penggunaan kerosin sebagai pelarut pada pengujian kandungan logam dalam pelumas dengan cara pelarutan langsung, dapat digantikan dengan pelarut organik yang lain seperti xilena (xylene), MEK (Methyl Ethyl Ketone)(ASTM, 2016a), n-heksana, thinner, dan MIBK (Methyl Isobuthyl Ketone) (Napitupulu et al., 2019). Hasil verifikasi pengujian dengan menggunakan xilena sebagai pelarut belum dicantumkan di ASTM D4628.

Xilena (xylene) memiliki nama lain dimethylbenzene atau ethylbenzene. Merupakan senyawa hidrokarbon aromatik berbentuk cair pada temperatur normal, bersifat non-polar, dan dapat dihasilkan dari minyak bumi(Fabri, 2000). Sifat xilena mirip dengan base oil pada pelumas, yang memiliki senyawa hidrokarbon aromatik, sehingga pelumas diharapkan akan larut baik dalam xilena. Xilena termasuk jenis pelarut yang mudah didapat di pasar. Xilena merupakan bahan kimia berbentuk cairan mudah terbakar, dapat menyebabkan iritasi, dan berbahaya apabila terhirup atau terkena kulit(Merck, 2018). Penggunaan APD (Alat Pelindung Diri) sangat direkomendasikan pada saat bekerja menggunakan xilena. Limbah sisa penggunaan xilena ditampung dan diperlakukan sebagai limbah kategori B3, tidak boleh dibuang langsung ke saluran pembuangan.

Menurut ISO 17025:2017, verifikasi adalah penyediaan bukti obyektif bahwa parameter yang diberikan memenuhi persyaratan yang ditentukan oleh standar yang diacu; sedangkan validasi metode adalah verifikasi terhadap metode yang dimodifikasi atau metode yang berbeda. Verifikasi atau validasi perlu dilakukan terhadap metode yang digunakan di laboratorium untuk menjamin mutu hasil pengujian dan memenuhi persyaratan akreditasi(BSN, 2018).

Validasi atau verifikasi metode merupakan persyaratan yang sangat penting dalam jaminan mutu pengujian. Parameter yang digunakan untuk menunjukkan unjuk kerja suatu metode pada umumnya meliputi: akurasi, presisi (repeatability), batas deteksi, batas kuantifikasi, linearitas, ketidakpastian, dan parameter statistik lainnya(Örnemark, 2014). Menurut ASTM D7740-11, parameter uji validasi metode pengujian kandungan logam dalam pelumas ditunjukkan dengan nilai presisi internal laboratorium (repeatability) dan presisi antar laboratorium (reproducibility) yang nilainya sangat tergantung dari konsentrasi logam dan jenisnya(ASTM, 2016b). Akurasi suatu pengujian AAS dapat diketahui dengan cara melakukan pengujian terhadap bahan acuan (SRM) yang nilainya tertelusur ke nilai acuan standar seperti NIST atau nilai acuan lain yang diakui(Usman et al., 2017).

\section{METODE}

\subsection{Alat dan Bahan}

Peralatan digunakan adalah Flame Atomic Absorption Spectrophotomer (FAAS), merek Perkin Elmer, model PinAAcle 900F yang kompatibel untuk pengujian langsung dari larutan organik (direct dilution method), dan alat-alat gelas laboratorium (glassware) seperti: labu ukur, pipet, dan gelas kimia.

Bahan pelarut yang digunakan dalam pengujian adalah xilena ( $p$-xylene) p.a dari Merck yang tidak mengandung pengotor, dengan kandungan $\mathrm{C} 6 \mathrm{H} 4-1,4-(\mathrm{CH} 3) 2$ mendekati 100\% (Merck, 2018). Bahan acuan menggunakan Single-Element Metallo-Organic CRM yang mengandung logam $(1000+10)$ $\mu \mathrm{g} / \mathrm{g}$, bahan acuan kalsium nilainya tertelusur ke NIST SRM 3109a, bahan acuan magnesium nilainya tertelusur ke NIST SRM 3131a, dan bahan acuan seng nilainya tertelusur ke NIST SRM 3168a.

\subsection{Cara Uji}

Pengujian kalsium dilakukan dengan cara menimbang sejumlah tertentu standar kemudian dilarutkan dan diencerkan dengan xilena. Pembuatan larutan standar dilakukan pada lima konsentrasi yang berbeda. Larutan standar dan blanko kemudian diukur dengan 
AAS pada panjang gelombang optimum 422,67 $\mathrm{nm}$. Salah satu larutan standar kemudian diukur sebagai contoh sebanyak 10 kali pengulangan. Langkah yang sama dilakukan untuk pengujian masing-masing logam yang lainnya pada panjang gelombang optimum yang berbeda, untuk magnesium pada $285,21 \mathrm{~nm}$ dan untuk seng pada 213,86 $\mathrm{nm}$. Pemilihan panjang gelombang optimum masing-masing unsur tersebut dilakukan dengan cara melakukan pengukuran terhadap salah satu larutan standar pada berbagai panjang gelombang, kemudian dilihat nilai absorbansi tertinggi yang diperoleh.

\subsection{Linearitas}

Linearitas diuji dengan cara mengukur absorbans dari sejumlah larutan standar. Kurva yang terbentuk dari hubungan absorbans yang terukur terhadap konsentrasi standar atau kurva kalibrasi. Nilai koefisien korelasi $\left(\mathrm{R}^{2}\right)$ yang diperoleh pada saat pengujian, pada umumnya menunjukkan linearitas dari pengujian yang dilakukan. Kurva dengan nilai $\mathrm{R}^{2} \geq 0,995$ biasanya dapat dinyatakan sebagai kurva yang linear(Van Loco et al., 2002).

\subsection{Presisi dan Akurasi}

Presisi dan Akurasi diuji dengan cara melakukan pengukuran terhadap salah satu larutan standar sebayak 10 kali pengulangan. keberterimaan Presisi repeatability dievaluasi dengan membandingan nilai RSD yang diperoleh dengan CV-Horwitz, apabila \%RSD yang diperoleh lebih kecil dari $0,67 \mathrm{CV}$-Horwitz maka repeatability dapat dinyatakan diterima. Akurasi ditentukan dengan menghitung \%recovery atau bias yang dihasilkan pada percobaan.

$$
\text { Bias, } \% \text { Recovery }=\frac{C_{u j i}}{C_{\text {acuan }}} \times 100 \%
$$

Keberterimaan akurasi apabila nilai \%rekoveri berada pada rentang $95 \%$ s.d. $105 \%$ (CIPAC, 1999).

\subsection{Batas deteksi dan batas kuantifikasi}

Batas deteksi (LoD) adalah jumlah analit terkecil yang masih dapat dideteksi pada pengukuran. Limit Kuantifikasi (LoQ) adalah nilai terkecil hasil pengukuran yang dapat dilaporkan. Nilai LoD dan LoQ, ditentukan dengan cara melakukan pengukuran terhadap larutan pelumas yang mengandung sedikit unsur yang ditambahkan (spike-sample), sebayak 10 kali pengukuran. LoD diperoleh dari hasil perhitungan 3 kali Standar Deviasi pengujian, dan LoQ diperoleh dari hasil perhitungan 10 kali Standar Deviasi pengujian (Örnemark, 2014).

\section{HASIL \& PEMBAHASAN}

Penggunaan $p$-xylene sebagai pelarut pada percobaan merupakan bahan substitusi dari kerosin. Pelumas yang digunakan dalam percobaan dapat larut dengan sempurna dalam xilena. Tidak terdapat gumpalan, kotor, atau bahan lain yang tidak larut dalam xilena. Xilena bersifat non-polar yang sama dengan sifat dari minyak pelumas. Pengujian terhadap larutan blanko diharapkan dapat menormalisasi gangguan dari matriks pada larutan.

Teknik pelarutan langsung (direct dilution) yang digunakan dapat mempercepat waktu pengujian karena tidak memerlukan proses persiapan contoh yang panjang dan rumit seperti pada teknik pelarutan dengan menggunakan asam (acid digestion). Pelumas dapat larut dengan baik dalam xilena tanpa mengganggu ikatan unsur logam dengan polimer. Pelarutan minyak pelumas dengan xilena, tidak perlu melalui tahap pembakaran, pengabuan, pelarutan, dan pengenceran; seperti apabila menggunakan teknik pelarutan dengan asam. Perlu diperhatikan, bahwa instrumen SSA yang digunakan harus dipastikan kompatibel (tahan) dengan pelarut organik, karena beberapa komponen dalam SSA pada umumnya hanya cocok untuk pelarut asam atau air. Komponen alat yang tidak cocok dengan pelarut dapat berakibat kerusakan terhadap alat dan bahaya kebakaran.

Linearitas diuji dengan menghitung nilai koefisien korelasi (R2) yang diperoleh dari kurva kalibrasi masing-masing unsur. Berdasarkan kurva kalibrasi yang diperlihatkan pada Gambar 1, Gambar 2, dan Gambar 3; diperolah persamaan linear dan nilai koefisien korelasi sebagai berikut: (1) $\mathrm{Ca}: \mathrm{y}=0,1001 \mathrm{x}+$ 0,01439 dan $\mathrm{R} 2(\mathrm{Ca})=0,99640$; (2) $\mathrm{Mg}: \mathrm{y}=$ $0,99694 x-0,01455$ dan $R 2(\mathrm{Mg})=0,99968$; dan (3) Zn: $y=0,32022 x+0,01398$ dan R2(Zn) $=0,99938$; dengan demikian kurva yang diperoleh dapat dianggap liner, karena nilai R2 $\geq 0,995$.

Presisi menunjukkan sejauhmana kedekatan data yang diperoleh dari suatu pengukuran berulang yang dilakukan terhadap satu contoh yang sama, metode dengan presisi yang dapat diterima dapat menunjukkan bahwa sistem yang dimiliki oleh suatu laboratorium sudah berjalan dengan baik. Nilai presisi pada percobaan yang dilakukan ditunjukkan pada Tabel 1. Pada percobaan ini diperoleh nilai 
presisi untuk masing-masing pengujian pada kondisi yang sama adalah sebagai berikut: Kalsium: \%RSD $<0.67^{*} \mathrm{CV}$-Horwitz $=2,168<$ 3,914; Magnesium: \%RSD $<0.67^{*} \mathrm{CV}-\mathrm{Horwitz}=$ $1,265<5,670$; dan Seng: \%RSD < $0.67^{*} \mathrm{CV}$ Horwitz $=0,665<4,736$; dengan demikian presisi metode dapat diterima.

Akurasi pengujian dapat diketahui dengan membandingkan antara nilai yang diperoleh pada saat pengujian dengan nilai acuan. Perhitungan akurasi dapat dilakukan dengan melakukan pengukuran menggunakan bahan acuan bersertifikat (CRM). Dengan menghitung bias atau \%recovery, maka dapat diketahui sejauhmana perbedaan antara hasil pengujian dengan nilai bahan acuan. Berdasarkan hasil percobaan yang tertera pada Tabel 2 , diperoleh $\%$ recovery untuk kalsium = $101 \%$, magnesium $=98 \%$, dan seng $=98 \%$; apabila mengacu kepada aturan CIPAC maka akurasi pengujian logam dapat diterima, karena masih berada pada rentang $95 \%-105 \%$.

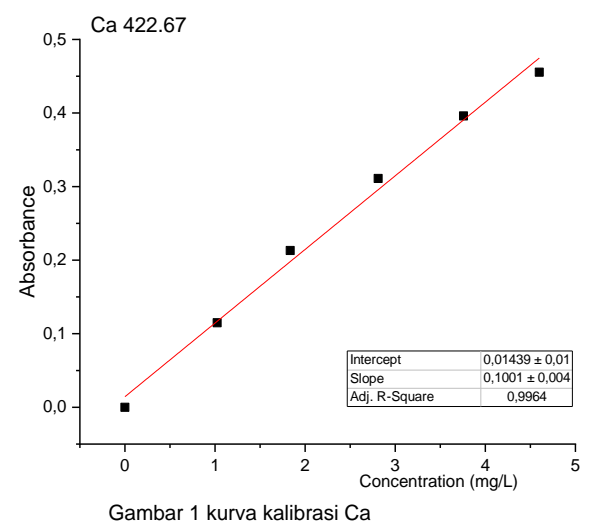

Batas deteksi (LoD) merupakan nilai analit terkecil yang dapat direspon oleh alat. Batas deteksi pengujian adalah tiga kali nilai simpangan baku, pada percobaan yang dilakukan diperoleh batas deteksi untuk masing-masing unsur sebagaimana yang tercantum pada Tabel 3 adalah sebagai berikut: kalsium $=0,013 \mathrm{mg} / \mathrm{L} ;$ magnesium $=0,002$ $\mathrm{mg} / \mathrm{L}$; dan Seng $=0,014 \mathrm{mg} / \mathrm{L}$. Pengukuran batas deteksi dilakukan terhadap blanko yang diberi sedikit standar pelumas (spiked-sample).

Batas kuantifikasi (LoQ) ditentukan nilainya sebagai sepuluh kali nilai simpangan baku. Berdasarkan percobaan, diperoleh nilai batas kuantifikasi untuk masing-masing unsur adalah sebagai berikut: kalsium $=0,043 \mathrm{mg} / \mathrm{L}$; magnesium $=0,007 \mathrm{mg} / \mathrm{L}$; dan Seng $=0,048$ $\mathrm{mg} / \mathrm{L}$. Persyaratan kandungan logam menurut SNI bervariasi sesuai dengan spesifikasi yang disyaratkan oleh masing-masing produsen. Kandungan logam dalam pelumas sangat tergantung dari aditif yang digunakan.
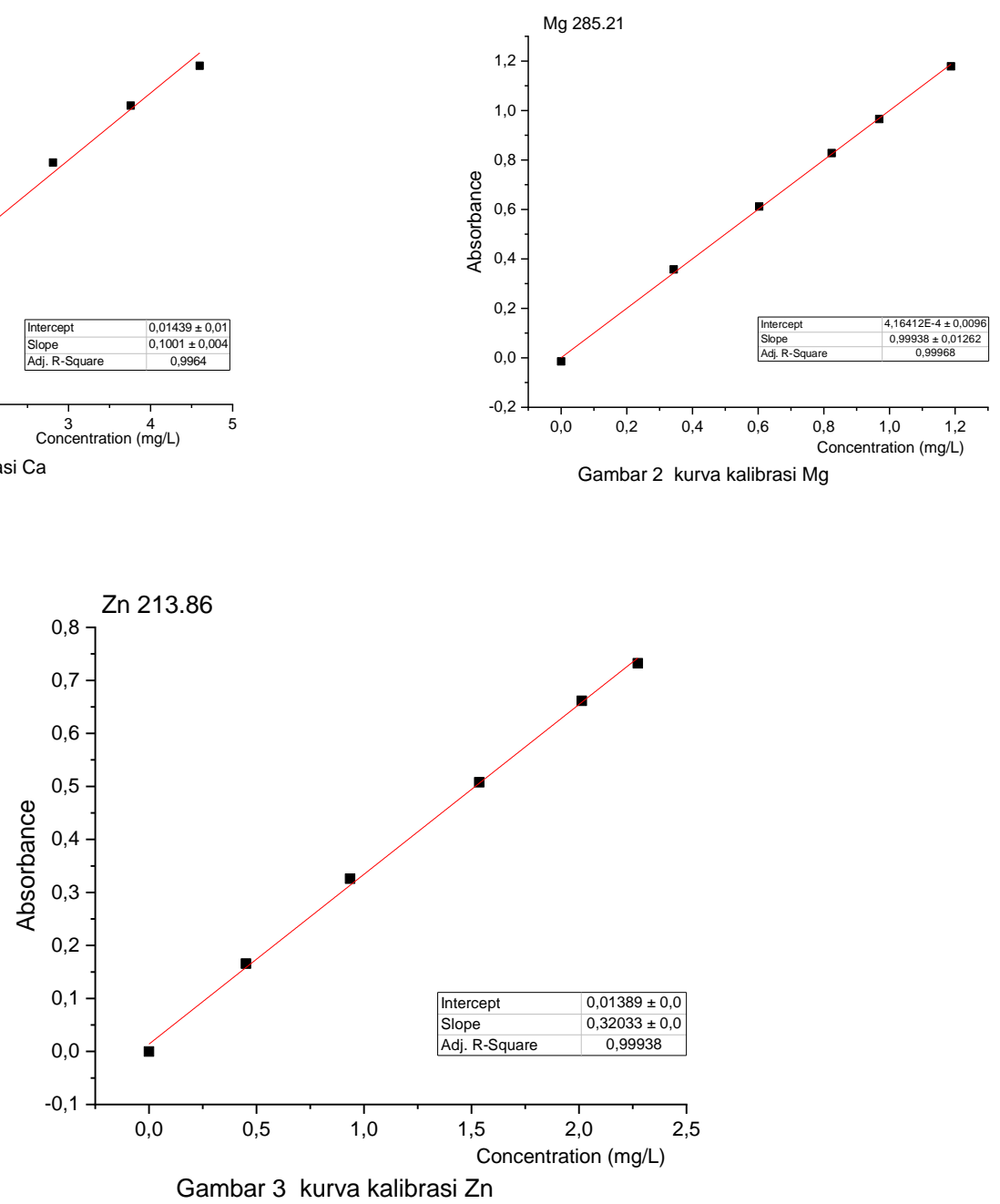
Tabel 1 Presisi.

\begin{tabular}{rrrrr}
\hline Pengukuran & Ca & Mg & Zn \\
\hline 1 & 2.918 & 0.85 & 1.522 \\
2 & 2.862 & 0.835 & 1.507 \\
3 & 2.687 & 0.832 & 1.506 \\
4 & 2.824 & 0.831 & 1.503 \\
5 & 2.826 & 0.833 & 1.497 \\
6 & 2.840 & 0.831 & 1.495 \\
7 & 2.857 & 0.833 & 1.502 \\
8 & 2.839 & 0.818 & 1.525 \\
9 & 2.869 & 0.818 & 1.516 \\
10 & 2.891 & 0.814 & 1.509 \\
\hline rata & $=$ & 2.841 & 0.830 & 1.508 \\
stdev & \%RSD & 0.0616 & 0.0105 & 0.0100 \\
0,67 CV-Horwitz $^{2}$ & $\mathbf{2 . 1 6 8}$ & $\mathbf{1 . 2 6 5}$ & $\mathbf{0 . 6 6 5}$ \\
& & $\mathbf{3 . 9 1 4}$ & $\mathbf{5 . 6 7 0}$ & $\mathbf{4 . 7 3 6}$ \\
\hline
\end{tabular}

Tabel 2 Akurasi.

\begin{tabular}{|c|c|c|c|}
\hline Pengukuran & $\mathrm{Ca}$ & $\mathrm{Mg}$ & $\mathrm{Zn}$ \\
\hline Nilai Acuan = & 2.8109 & 0.8450 & 1.5366 \\
\hline Bias $=$ & 0.011 & 0.018 & 0.018 \\
\hline \%Recovery = & 101.1 & 98.2 & 98.2 \\
\hline
\end{tabular}

Tabel 3 Nilai LoD dan LoQ.

\begin{tabular}{rrrrr}
\hline Pengukuran & \multicolumn{1}{c}{ Ca } & Mg & Zn \\
\hline 2 & 0.062 & 0.026 & 0.169 \\
3 & 0.067 & 0.026 & 0.176 \\
4 & 0.065 & 0.027 & 0.174 \\
5 & 0.066 & 0.027 & 0.170 \\
6 & 0.064 & 0.026 & 0.168 \\
7 & 0.062 & 0.027 & 0.179 \\
8 & 0.070 & 0.026 & 0.167 \\
9 & 0.056 & 0.028 & 0.170 \\
10 & 0.060 & 0.026 & 0.167 \\
rata2 $=$ & 0.069 & 0.026 & 0.163 \\
stdev $=$ & 0.064 & & 0.027 & 0.170 \\
LoD $=$ & 0.0043 & & 0.0007 & 0.0048 \\
LoQ $=$ & $\mathbf{0 . 0 1 3}$ & & $\mathbf{0 . 0 0 2}$ & $\mathbf{0 . 0 1 4}$ \\
& & $\mathbf{0 . 0 4 3}$ & & $\mathbf{0 . 0 0 7}$ \\
\hline
\end{tabular}


5.

\section{KESIMPULAN}

Pengujian kandungan kalsium, magnesium dan seng dalam pelumas dengan menggunakan AAS dan pelarut xilena dapat dilaksanakan dengan baik dan nilai yang diperoleh untuk parameter uji validasi yang dilakukan dapat diterima. Penggunaan pelarut organik (xilena) dapat memudahkan dan menyederhanakan proses persiapan contoh, dibandingkan dengan apabila menggunakan metode pelarutan contoh dengan asam.

Penggunaan AAS untuk pengujian kandungan logam di Industri pelumas diharapkan dapat mengurangi biaya investasi alat yang dikeluarkan oleh industri dalam memenuhi persyaratan SNI wajib, dibandingkan apabila menggunakan ICP-AES.

\section{UCAPAN TERIMA KASIH}

Penulis mengucapkan terima kasih kepada Kepala Balai Besar Bahan dan Barang Teknik, dan personil di laboratorium pelumas yang telah membantu penelitian ini.

\section{DAFTAR PUSTAKA}

ASTM. (2016a). ASTM D4628-16, Standard Test Method for Analysis of Barium, Calcium, Magnesium, and Zinc in Unused Lubricating Oils by Atomic Absorption Spectrometry. ASTM International, 05.02 . https://doi.org/10.1520/mnl10941m

ASTM. (2016b). ASTM D7740, Standard Practice for Optimization, Calibration , and Validation of Atomic Absorption Spectrometry for Metal Analysis of Petroleum Products and Lubricants. 11(Reapproved), $1-9$. https://doi.org/10.1520/D7740-11R16.2

ASTM. (2018). ASTM D5185-18, Standard Test Method for Determination of Additive Elements, Wear Metals, and Contaminants in Used Lubricating Oils and Determination of Selected Elements in Base Oils by Inductively Coupled Plasma Atomic Emission Spectrometry (ICP-AES). ASTM International, 05.02. https://doi.org/10.1520/mnl10959m

Bartels, T., \& Et.all. (2007). Lubricants and Lubrication. In Lubricants and Lubrication (pp. $1-850)$. https://doi.org/10.1002/9783527610341

BSN. (2012a). Klasifikasi dan spesifikasi Pelumas - Bagian 1: Minyak lumas motor bensin 4 (empat) langkah kendaraan bermotor. 1.

BSN. (2012b). Klasifikasi dan spesifikasi Pelumas - Bagian 2: Minyak lumas motor bensin 4 ( empat) langkah sepeda motor. 2.

BSN. (2012c). Klasifikasi dan spesifikasi Pelumas - Bagian 5: Minyak lumas motor diesel putaran tinggi. 5.

BSN. (2016). Klasifikasi dan spesifikasi Pelumas - Bagian 3: Minyak lumas motor bensin 2 ( dua ) langkah dengan pendingin udara. 3.

BSN. (2017a). Klasifikasi dan spesifikasi Pelumas - Bagian 4: Minyak lumas motor bensin 2 ( dua ) langkah dengan pendingin air. 4.

BSN. (2017b). Klasifikasi dan spesifikasi Pelumas - Bagian 7: Minyak lumas transmisi otomatis. 7.

BSN. (2018). SNI ISO/IEC 17025:2017, Persyaratan umum kompetensi laboratorium pengujian dan laboratorium kalibrasi.

CIPAC. (1999). Guidelines on method validation to be performed in support of analytical methods for agrochemical formulations. Cipac, 3807.

Fabri, J. (2000). Xylenes. Ulmann's Encyclopedia of Industrial Chemistry, 643-661.

https://doi.org/10.1002/14356007.a28

Holmberg, K., Andersson, P., \& Erdemir, A. (2012). Global energy consumption due to friction in passenger cars. Tribology International, 47, 221-234. https://doi.org/10.1016/j.triboint.2011.11. 022

Kemenperin. (2018). Permenperin No.25 Tahun 2018.

Merck. (2018). SDS p-xilena. Merck, 1253(1907), 1-13.

Merry Mitan, N., Saifulazwan Ramlan, M., Zainul Hakim Nawawi, M., \& Kindamas, Z. (2018). Preliminary study on effect of oil additives in engine lubricant on fourstroke motorcycle engine. Materials Today: Proceedings, 5(10), 2173721743.

https://doi.org/10.1016/j.matpr.2018.07.0 26

Nan, F., Xu, Y., Xu, B., Gao, F., Wu, Y., \& Li, Z. (2015). Tribological behaviors and wear mechanisms of ultrafine magnesium aluminum silicate powders as lubricant additive. Tribology International, 81(21), 199-208.

https://doi.org/10.1016/j.triboint.2014.09. 006

Napitupulu, R. M., Julia, D., \& Panggabean, A. 
S. (2019). Validasi Metode Penentuan Mn dalam Oli Lubrikan dengan Metode Pengenceran LAngsung Menggunakan Spektrofotometer Serapan Atom. Indo. J. Chem. Res., 6(2), 94-100.

Örnemark, B. M. and U. (2014). Eurachem Guide: The Fitness for Purpose of Analytical Methods - A Laboratory Guide to Method Validation and Related Topics, (2nd ed. 2014). Eurachem. https://doi.org/10.1016/S00142999(99)00500-2

Özcan, A., Yılmaz, D., Koç, N., \& Gaşan, H. (2019). Effect of Calcium Hexaborate Pentahydrate as a Lubricant Additive in Commercial Engine Oil. Transactions of the Indian Institute of Metals. https://doi.org/10.1007/s12666-0181483-9

Pouzar, M., Černohorský, T., \& Krejčová, A. (2001). Determination of metals in lubricating oils by X-ray fluorescence spectrometry. Talanta, 54(5), 829-835. https://doi.org/10.1016/S00399140(01)00338-1

Roslan, A., Ibrahem, A. S., \& Hadi, A. (2016). Metal additives composition and its effect on lubricant characteristic. AIP Conference Proceedings, 1774(October 2016). https://doi.org/10.1063/1.4965083

Srivyas, P. D., \& Charoo, M. S. (2019). Effect of lubricants additive: Use and benefit. Materials Today: Proceedings, 18, 47734781. https://doi.org/10.1016/j.matpr.2019.07.4 65

Uflyand, I. E., Zhinzhilo, V. A., \& Burlakova, V. E. (2019). Metal-containing nanomaterials as lubricant additives: State-of-the-art and future development. Friction, 7(2), 93-116. https://doi.org/10.1007/s40544-0190261-y

Usman, A. I., Seydou, H., \& Abubakar, A. (2017). Validation of Atomic Absorption Spectroscopy ( AAS ) for Trace Elements Analysis of Environmental Samples. Research and Review: Journal of Physics, 6(2), 8-13.

Van Loco, J., Elskens, M., Croux, C., \& Beernaert, H. (2002). Linearity of calibration curves: Use and misuse of the correlation coefficient. Accreditation and Quality Assurance, 7(7), 281-285. https://doi.org/10.1007/s00769-0020487-6

Vardhaman, B. S. A., Amarnath, M., Ramkumar, J., \& Mondal, K. (2020). Enhanced tribological performances of zinc oxide/MWCNTs hybrid nanomaterials as the effective lubricant additive in engine oil. Materials Chemistry and Physics, 253(August 2019), 123447. https://doi.org/10.1016/j.matchemphys.2 020.123447

Zmozinski, A. V., De Jesus, A., Vale, M. G. R., \& Silva, M. M. (2010). Determination of calcium, magnesium and zinc in lubricating oils by flame atomic absorption spectrometry using a threecomponent solution. Talanta, 83(2), 637643.

https://doi.org/10.1016/j.talanta.2010.10. 013 